\title{
BIOLOGICAL CONTROL OF TOMATO VERTICILLIUM WILT DISEASE BY TALAROMYCES FLAVUS
}

\author{
Laleh Naraghi' ${ }^{1 *}$ Asghar Heydari², Saeed Rezaee ${ }^{1}$, Mohammad Razavi², \\ Hanieh Jahanifar ${ }^{2}$, Elahe Mahmoodi Khaledi ${ }^{3}$
}

\begin{abstract}
${ }^{1}$ Department of Plant Pathology, College of Agriculture and Natural Resources, Science and Research Branch, Islamic Azad University, P.O. Box 14515/775, Tehran, Iran

${ }^{2}$ Plant Disease Research Department, Iranian Research Institute of Plant Protection, P.O. Box 1452, Tehran 19395, Iran

${ }^{3}$ Department of Microbiology, College of Science, Tehran University, P.O. Box 1452, Tehran, Iran
\end{abstract}

Received: January 19, 2010

Accepted: August 5, 2010

\begin{abstract}
In this study, Talaromyces flavus a fungal antagonist, was isolated from soil samples collected from tomato fields in Tehran and the Western Azarbayjan provinces of Iran. Antagonistic effects of T. flavus isolates against Verticillium albo-atrum (V. a.-a.), the causal agent of tomato wilt disease were investigated under laboratory and greenhouse conditions. Soil samples from tomato fields in the Varamin and Uremia regions of Tehran and the Western Azarbayjan provinces respectively, were cultured on selective medium. T. flavus colonies were recovered after three weeks. In the laboratory experiments, antagonistic effects of volatile and non-volatile extracts of T. flavus isolates on $V$. $a$.-a. growth were investigated. Among isolates, five that caused higher growth inhibition of $V$. $a$.-a. were selected for greenhouse experiments. In the greenhouse, first inoculum of $V$. $a$.-a. and treatments affected by $T$. flavus isolates were prepared. For comparison of the infection index in treatments, the greenhouse experiment was performed with a split plot arranged in a randomized complete block design with four replications. Result of greenhouse experiments on different types of T. flavus treatments indicated that there was no significant difference among them. However, among five T. flavus isolates, the most effective one was Tf-To-V-24 and Tf-To-U-36. In the experiment on the interaction between different T. flavus treatments and T. flavus isolates, a minimum infection index was observed when both soil and seed were treated with Tf-To-V-31. The overall results of this study show that it may be possible to manage tomato Verticillium wilt disease effectively by T. flavus.
\end{abstract}

Key words: tomato, Verticillium albo-atrum, antagonistic effects, Talaromyces flavus

\section{INTRODUCTION}

Tomato (Lycopersicon esculentum Mill.) is the second most important vegetable crop next to potato. The present world production is about 100 million tons of fresh fruit produced on 3.7 million hectars. Tomato production was reported in 144 countries (Bal and Abak 2007).

Iran is ranked seventh in the world as a tomato producer. In Iran tomato is planted on about 140000 hectares with an average yield of 37 tons per hectare (Alemzadeh Ansari and Mamghani 2008). Verticillium wilt is one of the most main diseases of tomato, which causes serious losses in the field (Paternotte and Van Kasteren 1993; Matta and Garibaldi 1997; Aminaee et al. 2006). Verticillium dahliae Kleb. and Verticillium albo-atrum Reinke and Berthold (V.a.-a.) are the causal agents of this disease (Pegg and Young 1982; Hutson and Smith 1982; Paternotte and Van Kasteren 1993; Kim et al. 2001; Mansoori and Smith 2005; Aminaee et al. 2006).

For controlling Verticillium wilt of tomato, cultural practices and the use of resistant cultivars are the most common strategies but they are either not available or not effective (Jones et al. 1995; Burbos and Skoudridakis 1996; Giotis et al. 2009). In recent years, biological control using fungal and bacterial antagonists were applied to control tomato diseases (Hanafi 2003; Giotis et al. 2009).

Talaromyces flavus (Klocker) Stulk and Samson is a fungal antagonist that has been used in biological control of some soil-borne pathogens such as $V$. dahliae, $V$. a.-a., Rhizoctonia solani and Sclerotinia sclerotiorum (Marois et al. 1984). Marois et al. (1982) showed that T. flavus decreased incidence of Verticillium wilt and increased yield of eggplant in England. Fahima and Henis (1997) showed that T. flavus decreased Verticillium wilt disease on eggplant at a $77 \%$ rate. The ability of this fungus occupying rhizosphere of tomato, cotton, and eggplant, and decreasing germination of microsclerotia of $V$. dahliae was reported by Marois et al. (1984).

The fungus (sexual form of Penicillium dangeardii) also was reported as a parasite of sclerotia of $R$. solani and S. sclerotiorum (McLaren et al. 1982). Tjamos and Fravel (1997) showed that T. flavus decreased Verticillium wilt on tomato plants. T. flavus and Aspergillus terreus were 
also reported to be the inhibitory agents of Verticillium wilt of olive trees in Greece (Tjamos 1991). Forty percent of non-volatile extracts (Talaron) of T. flavus are considered to affect the production of hydrogen peroxide due to the glucose oxidase enzyme and this gives antibacterial and antifungal characteristics to this fungus (Kim and Fravel 1990).

The objectives of this study were to investigate the antagonistic effects of T. Flavus isolates on $V$. a.-a. the causal agent of tomato wilt disease and to compare different application methods.

\section{MATERIALS AND METHODS}

The following experiments were conducted and executed in 2009.

\section{Isolation of $V . a .-a$. from the soil}

During 2008-2009, field soil samples were collected from tomato fields the Varamin area in the Tehran Province of Iran, and carried to the laboratory in plastic bags. Samples were air-dried, homogenized using a revolving jar mill and stored at $4^{\circ} \mathrm{C}$. For isolation of $V$. albo-atrum from soil, the wet sieving procedure was used (Christen 1981).

\section{Pathogenicity test}

An isolate of $V$. a.-a., obtained from tomato field soil was used in the study. This isolate was grown on tomato dextrose agar (PDA) at $22^{\circ} \mathrm{C}$ prior to inoculation. Spore suspenspensions were prepared from 3-week-old cultures by adding $10 \mathrm{ml}$ of sterile distilled water to each plate and scraping the cultures with a rubber spatula. Using a hoemocytometer, the inoculum concentration was adjusted to $10^{7}$ conidia per milliliter. Tomato seedlings of 'Early Urbuna $Y^{\prime}$ ' as a susceptible cultivar (Sahebani and Hadavi 2009) were inoculated at the 3rd-4th true leaf stage. These tomato seedlings were uprooted and inoculated by using the root-dip technique. Roots were washed with running water and placed for 60 minutes in conidia suspension. The inoculated seedlings were transplanted to pots containing a mixture of peatmoss, vermiculate and perlite $(1: 1: 1, \mathrm{v} / \mathrm{v} / \mathrm{v})$. Three replications of five plants were used. The plants were kept on the bench at $21-23^{\circ} \mathrm{C}$. Daylight was supplemented by fluorescent lights to provide a $12 \mathrm{~h}$ day length (Kim et al. 2001).
Disease symptoms were recorded approximately every 10 days for about one and a half months after inoculation. Disease severity was based on an arbitrary scale where 0 was assigned to a plant with no visual symptoms, 0.5 to a plant with symptoms on the cotyledon, 1 to a plant with one leaf infected, 1.5 when the second leaf was infected, 2 when the third leaf was infected and so on (Paplomatas et al. 1999).

\section{Isolation of $T$. flavus from soil}

Since T. flavus occupies rhizosphere of tomato (Marois et al. 1984), tomato fields in the Varamin and Uremia area in Tehran and the Western Azarbayjan provinces of Iran were selected for soil collection. Selective medium (TF medium) was adopted for isolation of fungus from the soil. This medium contained 11 distilled water, $39 \mathrm{~g}$ potato dextrose agar (PDA), $2.0 \mathrm{ml}$ of a $50 \%$ solution of lactic acid, $100 \mathrm{mg}$ streptomycin sulfate, $50 \mathrm{mg}$ chlorotetracycline, $50 \mathrm{mg}$ chloramphenicol, $4 \mathrm{mg}$ pimaricin, $30 \mathrm{mg}$ nystatine (Mycostatin, 4960 units $/ \mathrm{mg}$ ) and $0.5 \mathrm{~g}$ oxgall (Bile, bovine). Lactic acid and the antimicrobial agents were added as aqueous solutions to autoclaved PDA at about $50^{\circ} \mathrm{C}$. The medium was poured into Petri dishes (18 $\mathrm{ml} /$ dish). One $\mathrm{ml}$ of aliquots was removed from $10^{-2}$ to $10^{-3}$ dilutions (soil in water) during agitation with a magnetic stirrer and was spread on the TF medium (five plates per replication). Plates were incubated in the dark at $30^{\circ} \mathrm{C}$ for 7-8 days. T. flavus isolates were detected and identified on the TF medium, based on their colony morphology 10 days after incubation. Using the above described procedure, propagules of $T$. flavus were isolated from the soil samples (Marois et al. 1984).

Investigation of the antagonistic effects of volatile extracts of $T$. flavus on $V$. a.-a. in laboratory experiments

In this step, T. flavus isolates were separately cultured on Petri dishes containing PDA medium and incubated at $30^{\circ} \mathrm{C}$ for 36 hours. After this time, $9-\mathrm{mm}$ disks of $V$. $a .-a$. isolate, which were isolated from tomato field soil, were cultured on other Petri dishes containing PDA medium. These Petri dishes (without lids) were placed inversely on Petri dishes containing T. flavus isolates so that the pathogenic and antagonistic fungi affect each other. These Petri dishes were incubated at $25^{\circ} \mathrm{C}$. After two weeks, the diameter of $V$. a.-a. colonies were recorded and growth inhibition percents were evaluated as follows:

Colony diameter of $V$. $a$.- $a$. in the control - colony diameter of $V$. $a .-a$. in culture medium affected by volatile extract of $T$. flavus

Growth inhibition percents =

Colony diameter of $V . a .-a$. in the control

Investigation of the antagonistic effects of non-volatile extracts of T. flavus on $V$. a.-a. in laboratory experiments

For preparation of non-volatile extracts, T. flavus isolates were separately cultured on Czapek-Dox medium and placed on a shaker at $50 \mathrm{rpm}$ for ten days. In the next step, the culture media was filtered through filter paper. The filter paper had pores which were $0.45 \mu$ in diameter (Eziashi 2006). The culture filtrates of fungal isolates were then mixed with PDA medium at a $20 \%$ concentration separately. Culture filtrates mixed with PDA medium were transferred into Petri dishes. $V$. $a$.- $a$. which was isolated from tomato field soil was cultured on medium surface in every Petri dish when medium temperature attained $25^{\circ} \mathrm{C}$. After one week, the diameter of $V$. $a$.- $a$. colonies was recorded and growth inhibition percent was evaluated as described previously. 
Five T. flavus isolates that caused greater growth inhibition of $V$. a.-a. than the other isolates, were selected for the greenhouse experiments.

\section{Greenhouse experiments}

Plant inoculation with $V$. a.-a.

Preparation of $V$. a.-a. inoculum and the inoculation of the tomato plants were carried out according to the procedures described by Paplomatas et al. (1999).

\section{Preparation of T. flavus inoculum}

Preparation of $T$. flavus inoculum for every isolate was carried out separately as follows:

T. flavus isolated from soil was cultured in $1.6-\mathrm{cm}-$ wide $x$ 15-cm-high test tubes containing TF medium. After 5 days, $20 \mathrm{ml} \mathrm{SDW}$ was poured into $50 \mathrm{~cm}$-wide $x$ $80-\mathrm{cm}$-tall sterile plastic bag containing $250 \mathrm{~g}$ of peatmoss mixed with $10 \mathrm{ml}$ D-lactose monohydrate (20 g/lit). Plastic bags were incubated at $30^{\circ} \mathrm{C}$ for 30 days. The content of each plastic bag was emptied after completely covering the surface of rice bran with T. flavus hyphae. The number of T. flavus ascospores in each $g$ of rice bran was then determined using a hemocytometer. In this procedure, one gram of rice bran was suspended in $10 \mathrm{ml}$ SDW and the number of ascospores in one $g$ of rice bran was determined by counting ascospores in one $\mathrm{ml}$ of this prepared suspension. T. flavus inoculum was added to the soil in the pots at $10^{7}$ ascospores per $g$ soil (Chet and Baker 1981). For seed treatment preparation, seed tomato tubers were floated in this inoculum.

Study of the antagonistic effects of T. flavus isolates on tomato Verticillium wilt disease

The experiment for the study on the effect of $T$. flavus isolates on the pathogenicity of $V$. a. $-a$. was carried out as follows:

The experiment was performed as a split plot arranged in a randomized complete block design with four replications. The main-factor was using different types of T. flavus treatments at three levels (1 - soil, 2 - seed, 3 - both soil and seed ) and the sub-factor was different fungal isolates at seven levels (from 1 to 5 : one of five T. flavus isolates $+V . a-a ., 6: V$. a-a., 7: without fungal inoculum).

Incoculated plants were kept at $22^{\circ} \mathrm{C}$ in the greenhouse under a $12 \mathrm{~h}$ light period. Disease symptoms were recorded approximately every 10 days for about one and a half months after inoculation. Disease severity was based on an arbitrary scale where 0 was assigned to a plant with no visual symptoms, 0.5 to a plant with symptoms on the cotyledon, 1 to a plant with one leaf infected, 1.5 when the second leaf was infected, 2 when the third leaf was infected and so on (Paplomatas et al. 1999). Data were analyzed by ANOVA (Analysis of Variance) using the MS TAT C statistical software, while means were separated by Duncan's multiple range test.

\section{RESULTS}

Isolation of $V$. $a$.- $a$. from soil and the pathogenicity test

After four weeks, inoculated plants exhibited stunting, chlorosis, and defoliation of lower leaves. The leaves were yellow at the edges and between veins. This discoloration occured on both sides of the leaf. Leaflets showed a characteristic V-shaped or fann shaped yellowing, with the widest part of the $\mathrm{V}$ on the leaf edge. Browning of the vascular system was seen by cutting the stem open with a knife. This brown discoloration inside the stem extended from the roots of the plant to the top (Pohronezny 1991).

In this pathogenicity test, infection index for infected plant was 4.25 .

\section{Isolation of T. flavus from soil}

As table 1 shows, fifteen T. flavus isolates were obtained from the tomato field soil of the Varamin and Uremia regions of Tehran and the Western Azarbayjan provinces.

Table 1. Inhibitory effects on $V$. a.-a. growth mediated by volatile and non-volatile extracts of $T$. flavus isolates

\begin{tabular}{|c|c|c|c|}
\hline \multirow{2}{*}{ Code of T. flavus isolate } & \multirow{2}{*}{ Collection region } & \multicolumn{2}{|c|}{ Percentage inhibition of $V . a$ - $a$. mycelium growth } \\
\cline { 3 - 4 } & & volatile extracts & non-volatile extracts \\
\hline Tf-To-V-24 & Varamin & 54.72 & 73.00 \\
\hline Tf-To-V-25 & Varamin & 45.94 & 72.22 \\
\hline Tf-To-V-26 & Varamin & 46.62 & 73.33 \\
\hline Tf-To-V-27 & Varamin & 45.94 & 72.77 \\
\hline Tf-To-V-28 & Varamin & 33.33 & 77.66 \\
\hline Tf-To-V-29 & Varamin & 50.00 & 80.88 \\
\hline Tf-To-V-30 & Varamin & 85.00 & 80.77 \\
\hline Tf-To-V-31 & Varamin & 35.00 & 78.77 \\
\hline Tf-To-V-32 & Varamin & 31.81 & 83.66 \\
\hline Tf-To-V-33 & Varamin & 31.66 & 73.11 \\
\hline Tf-To-U-34 & Uremia & 18.33 & 94.66 \\
\hline Tf-To-U-35 & Uremia & 33.33 & 95.22 \\
\hline Tf-To-U-36 & Uremia & 18.18 & 75.22 \\
\hline Tf-To-U-37 & Uremia & 48.33 & 92.55 \\
\hline Tf-To-U-38 & Uremia & & \\
\hline
\end{tabular}


Investigation of the antagonistic effects of volatile extracts of T. flavus on $V$. a.-a. in laboratory experiments

According to table 1, variable inhibitory effects on $V$. a.-a. growth were induced by different $T$. flavus isolates. Maximum inhibitory effect was mediated by isolate TfTo-V-31 and minimum inhibitory effect by isolate Tf-To$\mathrm{U}-37$.

Investigation of the antagonistic effects of non-volatile extracts of T. flavus on $V$. a.-a. in laboratory experiments

As table 1 indicates different inhibitory effects on $V$. a.-a. growth were induced by T. flavus isolates. Maximum inhibitory effect was mediated by isolate Tf-To-U-36 and minimum inhibitory effect was caused by isolate TfTo-V-26 and Tf-To-V-28.

Based on total inhibitory effects mediated by volatile and non-volatile extracts, the following $T$. flavus isolates were selected for the greenhouse experiments: Tf-To-V-31, Tf-To-U-38, Tf-To-V-30, Tf-To-U-36 and Tf-To-V-24.

Evaluation of the antagonistic effects of T. flavus isolates on tomato Verticillium wilt disease

As table 2 shows, treatments affected by the main factor (different types of $T$. flavus treatments) were placed in one statistical group. The mean minimum infection index was 1.64 when soil and seed treatment were applied.

Treatments affected by the sub-main factor (different fungal isolates) were placed in five statistical groups. The minimum infection index mean was 1.25 in the case of Tf-To-V-24 + V. $a-a$. and Tf-To-U-36 + V. $a-a$.

In the experiment of interaction between main factor and sub-main factor, all treatments were placed in 10 statistical groups. Minimum infection index (0.62) was observed when both soil and seed were treated with Tf-To-V-31 (Table 3).

Table 2. The effects of main factor (different types of T. flavus treatments) and sub-main factor (different fungal isolates) on Verticillium wilt infection index on tomato plants

\begin{tabular}{|c|c|c|c|}
\hline Variable source & Treatment & Infection index mean & Statistical grouping* \\
\hline \multirow{3}{*}{ Main factor } & seed & 1.83 & $\mathrm{a}$ \\
\hline & soil & 1.71 & $\mathrm{a}$ \\
\hline & soil and seed & 1.64 & $\mathrm{a}$ \\
\hline \multirow{7}{*}{ Sub-main factor } & V. $a-a \cdot($ control + ) & 4.25 & $\mathrm{a}$ \\
\hline & Tf-To-U-38 + V. $a-a$. & 2.21 & $\mathrm{~b}$ \\
\hline & Tf-To-V-30 + V. a-a. & 1.71 & $\mathrm{bc}$ \\
\hline & Tf-To-V-31+ V. $a-a$ & 1.46 & $\mathrm{c}$ \\
\hline & Tf-To-U-36 + V. $a-a$. & 1.25 & $\mathrm{c}$ \\
\hline & Tf-To-V-24 + V. $a-a$ & 1.25 & $\mathrm{c}$ \\
\hline & $\begin{array}{l}\text { without fungal inoculum } \\
\text { (the control -) }\end{array}$ & 0 & d \\
\hline
\end{tabular}

*treatments marked by the same letter (s) are not significantly different $(\mathrm{p}>0.01)$

V. a.-a. - Verticillium albo-atrum

Table 3. The interactive effects between main factor and sub-main factor (all treatments) on Verticillium wilt infection index on tomato plants

\begin{tabular}{|c|c|c|}
\hline Treatments & Infection index mean & Statistical grouping* \\
\hline V. a-a. (control +) & 4.25 & $\mathrm{a}$ \\
\hline Tf-To-U-38 (seed) + V. $a-a$. & 2.75 & $\mathrm{~b}$ \\
\hline Tf-To-U-38 (soil \& seed) + V. $a-a$. & 2.37 & c \\
\hline Tf-To-V-30 (soil) + V. $a-a$ & 1.87 & $\mathrm{~d}$ \\
\hline Tf-To-V-31 (soil) + V. $a-a$. & 1.87 & $\mathrm{~d}$ \\
\hline Tf-To-V-31 (seed) + V. a-a. & 1.87 & $\mathrm{~d}$ \\
\hline Tf-To-V-30 (seed) + V. $a-a$. & 1.75 & de \\
\hline Tf-To-U-38 (soil) + V. $a-a$. & 1.50 & def \\
\hline Tf-To-V-30 (soil \& seed) + V.a-a. & 1.50 & def \\
\hline Tf-To-U-36 (soil \& seed) + V. a-a. & 1.37 & ef \\
\hline Tf-To-V-24 (soil \& seed) + V. $a-a$ & 1.37 & ef \\
\hline Tf-To-U-36 (soil) + V.a-a. & 1.25 & $\mathrm{f}$ \\
\hline Tf-To-V-24 (soil) + V. $a-a$ & 1.25 & $\mathrm{f}$ \\
\hline Tf-To-V-24 (seed) + V. a-a. & 1.12 & $\mathrm{f}$ \\
\hline Tf-To-U-36 (seed) + V.a-a. & 1.12 & $\mathrm{f}$ \\
\hline Tf-To-V-31 (soil \& seed) + V. $a-a$. & 0.62 & $\mathrm{~g}$ \\
\hline Without fungal inoculum (the control - ) & 0 & $\mathrm{~h}$ \\
\hline
\end{tabular}

*treatments marked by the same letter (s) are not significantly different $(\mathrm{p}>0.01)$

V. a.-a. - Verticillium albo-atrum 


\section{DISCUSSION}

The overall results of this study show that it may be possible to manage tomato Verticillium wilt disease efficiently by seed treatment with effective T. flavus isolates. The inhibitory effect of volatile and non-volatile extracts of several bacterial and fungal microorganisms on growth and activity of some fungal pathogens were demonstrated in previous studies. For example, the volatile extracts of F. oxysporum resulted in induction of resistance to chickpea (Cicer arietinum L.) against fungal pathogens (Cherif et al. 2007). The efficiency of non-volatile extracts of some bacterial and fungi including A. flavus, A. ochraceus, Penicillium aurantiogriseum, Bacillus subtilis and Trichoderma harzianum for controlling antracnose of cowpea (Vigna unguiculata L. Walp.) were reported (Adebanjo and Bankole 2004).

In other studies, the effect of these extracts on different soil-borne fungal diseases of tomato were also shown (Josh et al. 2009). In another study, the effect of volatile and nonvolatile extracts of $T$. flavus on root-rot disease of lettuce (Lactuca sativa L.) caused by Sclerotinia minor was shown in the laboratory and greenhouse experiments. Results of this study confirmed that the inhibitory effect of variable components of extracts on pathogenic agent growth was different (El-Tarabily et al. 2000). Results of another study on the use of non-volatile extracts such as chitinase produced by T. harzianum and T. flavus were effective for controlling soybean stem white rot disease caused by S. sclerotiorum and bean stem rot caused by $S$. Rolfsii, respectively (Madi et al. 1997; Menendez and Godeas 1998).

Other examples of fungal metabolites such as glucanase secreted by Zygorrhynchus moelleri and glucose oxidase produced by $T$. flavus have also been effective against some soil borne plant pathogenic fungi (Brown 1987; Murrary et al. 1997).

Results of studies on the use of T. flavus in biocontrol of pathogenic fungi showed that $T$. flavus was an important antagonist on $V$. dahliae and $V$. a.-a. (Tjamos and Paplomatas 1987; Wikins et al. 2000; Vidhyasekaren 2004). Kim and Fravel (1990) showed that glucose oxidase produced by $T$. flavus prevented formation of microsclerotia of $V$. dahliae. However, Proksa et al. (1992) showed that 2-methyl sorbic acid secreted by T. flavus showed an inhibitory effect on the growth of V. a.-a.

The differences between the results of the laboratory experiments in the present study and the previous ones could have been due to the extract concentration. It was reported that there was a minimum concentration $(0.1 \mu \mathrm{g} /$ $\mathrm{ml}$ ) for every effective component of non-volatile extracts of F. oxysporum (Cyclosporin) used for growth inhibition of S. sclerotiorum (Rodriguez et al. 2006 ). In another part of this study, using effective T. flavus isolates as seed treatment decreased Verticillium wilt infection index in greenhouse conditions. These results agree with those of some previous studies (Soytong and Ratanacherdchai 2005; Kulikov et al. 2006). The minor differences between the results of this study and those of the previous ones could be due to method of seed treatment with $T$. flavus isolates and to the intervals before sowing (Nagtzaam and Bollen 1997).

Overall results of our study indicate that the use of effective $T$. flavus isolates could be an effective strategy for controlling Verticillium wilt disease of tomato. The present findings may have a practical application in the formulation of disease management strategies in the field. The promising results of this study may be used for reduction of losses caused by plant diseases, to minimize the application of chemical fungicides, protect the environment and preserve biological resources in a sustainable agricultural system.

\section{REFERENCES}

Adebanjo A., Bankole S.A. 2004. Evaluation of some fungi and bacteria for biocontrol of anthracnose disease of cowpea. J. Basic Microbiol. 44 (1): 3-9.

Alemzadeh Ansari N., Mamghani R. 2008. A study on adaptation of tomato ecotypes from northern latitudes under southern Iran conditions. J. Appl. Hort. 10: 29-33.

Aminaee M. M., Mansoori B., Ershad D. 2006. A study on Verticillium wilt of tomato in Kerman province. In: Proceedings of the 17th Iranian Plant Protection Congress (M. Abbasi, F. Aliabadi, eds.). University of Tehran, Karaj, p. 163.

Bal U., Abak K. 2007. Haploidy in tomato (Lycopersicon esculentum Mill.): a critical review. J. Euphytica 158 (1-2): 1-9.

Bourbos V.A., Skoudridakis M.T. 1996. Soil solarization for the control of Verticillium wilt of greenhouse. Phytoparasitica 24 (4): $277-280$

Brown A.E. 1987. Activity of glucanases of Zygorrhynchus moelleri in relation to antagonism against some soil borne plant pathogenic fungi. J. Phytopathol. 120 (4): 298-309.

Cherif M., Arfaoni A., Khaiem A. 2007. Phenolic compounds and their role in biocontrol and resistance of chickpea to fungal pathogenic attacks. Tunisian J. Plant Protect. 2: 7-21.

Chet I., Baker R. 1981. Isolation and biocontrol potential of Trichoderma hamatum from soil naturally suppressive to Rhizoctonia solani. Phytopathology 71: 286-290.

Christen A.A. 1981. A selective medium for isolating Verticillium albo-atrum from soil. Phytopathology 72: 47-49.

El-Tarabily K.A., Soliman M.H., Nassar A.H., Al-Hassani H.A., Sivasithamparam K., Mc Kenna F., Hardy G.E. 2000. Biological control Sclerotinia minor using a chitinolytic bacterium and actinomycetes. Plant Pathol. 49: 573-583.

Eziashi E.L., Uma N.U., Adekunle A.A., Ariede C.E. 2006. Effect of metabolites produced by Trichoderma species against Ceratocystis paradoxa in culture medium. African J. Biotech. 5 (9): 703-706.

Fahima T., Henis Y. 1997. Increasing of Trichoderma hamatum and Talaromyces flavus on the root of safe and useful hosts. p. 296-322. In: "Biological Control of Soil-Borne Plant Pathogens Hornby" (A. Alavi, A. Ahoonmanesh, eds.). Tehran, Iran.

Giotis C., Markelou E., Theodoropoulou A., Toufexi E., Hodson R., Shotton P., Shiel R., Cooper J., Leifert C. 2009. Effect of soil amendments and biological control agents (BCAs) on soil-borne root disease caused by Pyrenochaetu lycopersici and Verticillium albo-atrum in organic greenhouse tomato production systems. Eur. J. Plant Pathol. 123: 387-400.

Hanafi A. 2003. Integrated Production and Protection in Greenhouse Tomato in Morocco. p. 192-197. In: “Tomate Sous Abri" Scientific Publication of CTIFL. 2003. Editions Centre Technique Interprofessionnel des Fruits et Légumes, 232 pp.

Hutson R.A., Smith I.M. 1982. The response of tomato seedling roots to infection by Verticillium albo-atrum or Fusarium oxysporum f. sp. lycopersici. Ann. Appl. Biol. 102 (1): 89-97. 
Jones J.P., Gilreath J.P., Overman A.J. 1995. Control of soil-borne diseases of mulched tomato by fumigation. Proc. Fla. State Hort. Soc. 108: 201-203.

Josh D., Hooda K.S., Bhatt J.C., Mina B.L., Gupta H.S. 2009. Suppressive effects of composts on soil-borne and foliar diseases of french bean in the field in the Western Indian Himalayas. Crop Protect. 28 (7): 608-615.

Kim K.K., Fravel D.R. 1990. Glucose oxidase as the antifungal principle of talaron from Talaromyces flavus. Can. J. Microbiol. 36 (11): 760-764.

Kim J.T., Park I.H., Lee H.B., Hahm Y.I., Yu S.H. 2001. Identification of Verticillium dahliae and Verticillium albo-atrum causing wilt of tomato in Korea. Plant Pathol. J. 17 (4): 222-226.

Kulikov S., Alimova F., Zakharova N., Nemtsev S., Varlamov V. 2006. Biological preparations with different mechanisms of action for protecting tomato against fungal diseases. Appl. Biochem. Microbiol. 42: 77-83.

Madi L., Katan T., Katan J., Henis Y. 1997. Biological control of Sclerotium rolfsii and Verticillium dahliae by Talaromyces flavus is mediated by different mecchanisms. Phytopathology 87: 1054-1060.

Mansoori B., Smith C.J. 2005. Elicitation of ethylene by Verticillium albo-atrum phytotoxins in tomato. J. Phytopathol. 153 (3): 143-149.

Marois J.J., Jahnson S.A., Dunn M.T., Papavizas G.C. 1982. Biological control of Verticillium wilt of eggplant in the field Plant Dis. 6 (12): 1166-1168.

Marois J.J., Fravel D.R., Papavizas G.C. 1984. Ability of Talaromyces flavus to occupy the rhizosphere. Soil Bio. Biochem. 16 (4): 387-390.

Matta A., Garibadli A. 1997. Control of Verticillium wilt of tomato by preinoculation with avirulent fungi. Eur. J. Plant Pathol. 83 (1): 457-462.

McLaren D.L., Huang H.C., Rimmer S.R. 1982. Hyphal interactions occurring between Sclerotinia sclerotiorum and Penicillium vermiculatum. Can. J. Plant Pathol. 4, p. 308.

Menendez A.B., Godeas A. 1998. Biological control of Sclerotinia sclerotiorum attacking soybean plants: degradation of the cell wall of this pathogen by Trichoderma harzianum. Mycopathologia 142 (3): 153-160.

Murrary F.R., Liewellyn D.J., Peacock W.J., Dennis E.S. 1997. Isolation of the glucose oxidase gene from Talaromyces flavus and characterization of its role in the biocontrol of Verticillium dahliae. Curr. Genet. 32 (5): 367-375.

Nagtzaam M.P., Bollen G.J. 1997. Colonization of roots of eggplant and tomato by Talaromyces flavus from coated seed. Soil Biol. Biochem. 29 (9-10): 1499-1507.

Paplomatas E.J., Elena K., Tsagkarakou A. 1999. Screening Tomato, Cucumber, Watermelon and Melon Rootstocks for Resistance to Verticillium dahliae. EPPO/MPU Conference on Cucurbitaceous and Solanaceous Vegetable Diseases in the Mediterranean Area. 11-14 October 1999. Kerkyra, Greece, p. 30.

Paternotte S.J., Van Kesteren H.A. 1993. A new aggressive strain of Verticillium albo-atrum in Verticillium resistant cultivars of tomato in the Netherlands. Eur. J. Plant Pathol. 99 (3): 169-172.

Pegg G.F., Young D.H. 1982. Purification and characterization of chitinase enzymes from healthy and Verticillium albo-atrum infected tomato plants, and from V. albo-atrum. Physiol. Plant Pathol. 21 (3): 389-398.

Pohronezny K. 1991. Verticillium wilt. p. 12-24. In: “Compendium of Tomato Diseases" (J.B. Jones, J.P. Jones, R.E. Stall, T.A. Zitter, eds.). APS Press, St. Paul, MN, USA.
Proksa B., Adamcova J., Fuska J. 1992. 2-methylsorbic acid, an antifungal metabolite of Penicillium vermiculatum. J. Appl. Microbiol. Biotech. 37 (4): 443- 445.

Rodriguez M.A., Cabrera G., Godeas A. 2006. Cyclosporine a from a nonpathogenic Fusarium oxysporum suppressing Sclerotinia sclerotiorum. J. Appl. Microbiol.100 (3): 575-586.

Sahebani N., Hadavi N. 2009. Induction of $\mathrm{H}_{2} \mathrm{O}_{2}$ and related enzymes in tomato roots infected with root-knot nematode (Meloidogyne javanica) by several chemical and microbial elicitors. Biocontrol Sci. Technol. 19 (3): 301-313.

Soytong K., Ratanacherdchai K. 2005. Application of mycofungicide to control late blight of tomato. J. Agric. Technol. 1: 19-32.

Tjamos E.C. 1991. Recovery of olive tree with Verticillium dahliae after individual application of soil solarization in stablished olive orchards. Plant Dis. 75 (6): 557-562.

Tjamos E.C., Fravel D.R. 1997. Distribution and establishment of the biocontrol fungus Talaromyces flavus in soil and on roots of solanaceous crops. Crop Protect. 16 (2): 135-139.

Tjamos E.C., Paplomatas E.J. 1987. Effect of soil solarization on the survival of fungal antagonists of Verticillium dahliae. EPPO Bull. 17 (4): 645-653.

Vidhyasekaren P. 2004. Concise Encyclopedia of Plant Pathology. 1st ed. Haworth Press Inc., Binghamton, NY.

Wikins T.A, Rajasekaran K., Anderson D.M. 2000. Cotton biotechnology. Critical Rev. Plant Sci. 19: 511-550.

\section{POLISH SUMMARY}

\section{BIOLOGICZNE ZWALCZANIE UWIĄDU POMIDORA PRZY POMOCY GRZYBA TALAROMYCES FLAVUS}

W pracy przedstawiono wyniki badań nad antagonistycznym grzybem Talaromyces flavus, wyizolowanym z próbek gleby zebranych z polowych upraw pomidora w Tehranie i zachodnim Azarbayjanie, prowincjach Iranu. W warunkach laboratoryjnych i szklarniowych, badano antagonistyczny wpływ izolatów T. flavus przeciwko czynnikowi sprawczemu uwiądu pomidorów - Verticillium albo-atrum (V.a.-a.). Próbki gleby zebrane w regionach Varamin i Uremia (Tehran) oraz zachodnich prowincjach Azarbayjanu, hodowano na pożywce selektywnej. Trzy tygodniowe kultury grzyba T. flavus wykorzystano do dalszych badań. $\mathrm{W}$ doświadczeniach laboratoryjnych badano antagonistyczny wpływ lotnych i nielotnych ekstraktów pochodzących z izolatów grzyba $T$. flavus na wzrost $V$. a.-a. Do badań szklarniowych wybrano pięć izolatów T. flavus znacznie ograniczających wzrost V.a.-a. Przed przystąpieniem do doświadczeń szklarniowych, przygotowano inokulat $V$. a.-a. oraz różne ekspozycje grzyba T. flavus. W celu porównania indeksu porażenia poszczególnych wariantów, doświadczenia szklarniowe przeprowadzono $\mathrm{w}$ na pojedynczo rozszczepionych poletkach $\mathrm{w}$ układzie bloków losowanych w czterech powtórzeniach. Wyniki badań szklarniowych, nie wykazały istotnej różnicy pomiędzy kombinacjami z wykorzystaniem grzyba T. flavus, choć spośród pięciu badanych izolatów T. flavus, najskuteczniejsze okazały się kombinacje Tf-To-V-24 i Tf-To-U-36. Badając interakcję $\mathrm{w}$ różnych kombinacjach z grzybem $T$. flavus, najniższy indeks porażenia stwierdzono zarówno w glebie, jak i nasionach traktowanych Tf-To-V-31. Wyniki badań wskazują na możliwość skutecznego ograniczania występowania uwiądu pomidora przy pomocy grzyba T. flavus. 